\title{
KONSUMSI MAKANAN MANIS TERHADAP TINGKAT KEJADIAN KARIES PADA ANAK USIA SEKOLAH DASAR (Studi Literatur)
}

\author{
Nurhaeni
}

\begin{abstract}
Abstrak
Pada umumnya anak sangat menyukai makanan manis khususnya cokelat, permen, dan kue-kue manis, tapi sangat disayangkan kesadaran anak untuk selalu menjaga kebersihan mulut masih kurang. Oleh karena itu karies gigi banyak dijumpai pada anak usia sekolah. Tujuan penelitian ini adalah untuk mengetahui hubungan antara mengonsumsi makanan manis dengan tingkat kejadian karies pada anak usia sekolah dasar. Penelitian ini menggunakan pendekatan deskriptif kualitatif, dan jenis penelitian yang digunakan adalah Studi Literatur. Hasil studi pustaka menunjukkan bahwa terdapat adanya hubungan yang signifikan antara mengonsumsi makanan manis terhadap tingkat kejadian karies. Dapat disimpulkan bahwa siswa yang memiliki tingkat konsumsi makanan manis tinggi akan memiliki resiko tinggi untuk terjadinya karies gigi, sedangkan siswa yang rendah konsumsi makanan manis akan mempunyai resiko yang rendah terhadap kejadian karies.
\end{abstract}

Kata kunci: Makanan Manis, Karies Gigi, Anak Usia Sekolah

\section{PENDAHULUAN}

Kerusakan gigi dapat mempengaruhi kesehatan tubuh lain karena gigi juga merupakan kesatuan dengan anggota tubuh, yang tentunya akan mengganggu aktivitas sehari-hari. Kesehatan gigi sangat erat kaitannya dengan apa yang kita konsumsi. Salah satu faktor yang dapat merusak gigi adalah makanan dan minuman, ada makanan dan minuman yang dapat merusak gigi dan ada pula makanan yang dapat menyehatkan gigi.(Rahman, E dkk, 2018).

Salah satu kerusakan gigi yang paling umum diderita oleh anak-anak adalah karies. Karies gigi merupakan penyakit yang banyak menyerang anak-anak maupun dewasa, baik pada gigi susu maupun gigi permanen. Karies gigi merupakan sebuah penyakit infeksi yang merusak struktur gigi, penyakit ini menyebabkan gigi berlubang, menyebabkan nyeri, gangguan tidur, penanggalan gigi, infeksi, berbagai kasus berbahaya dan bahkan kematian.(Norfai dkk, 2017)

Karies gigi yang banyak dialami oleh anak usia sekolah adalah biasasnya disebabkan oleh beberapa faktor diantaranya kegemaran mengonsumsi makanan manis. Makanan manis merupakan makanan yang mengandung gula dan sukrosa, yang dapat menyebabkan terjadinya karies gigi atau gigi berlubang pada anak.(Mendur, S dkk, 2017)

Berdasarkan hasil peneltian Galih Saputra, 2010 dalam penelitiannya berjudul "Hubungan Antara Konsumsi Makanan Kariogenik dan Kebiasaan Menggosok Gigi Terhadap Timbulnya Karies Gigi Sulung Pada Anak Usia 46 Tahun di Tiga TK Kelurahan Sudiang Raya Kecamatan Biring Kanaya Kota Makassar". Dari hasil penelitiannya ditemukan adanya hubungan konsumsi makanan kariogenik/manis dengan kejadian karies gigi pada anak usia 4-6 tahun di Kelurahan Sudiang Raya Kecamatan Biring Kanaya Kota Makassar.

Berdasarkan latar belakang di atas peneliti tertarik untuk meneliti apakah terdapat hubungan mengonsumsi makanan manis terhadap tingkat kejadian karies di dalam kehidupan sehari-hari terutama pada anak usia sekolah. Serta peneliti berharap hasil penelitian ini dapat dipakai untuk pembelajaran dan bahan 
kajian bagi orang tua dalam menjaga dan merawat gigi anak-anak.

\section{METODE PENELITIAN}

Penelitian ini menggunakan pendekatan deskriptif kualitatif, dan jenis penelitian yang digunakan adalah Studi Literatur.

\section{HASIL DAN PEMBAHASAN}

Karies gigi merupakan penyakit yang banyak menyerang anak-anak maupun dewasa, baik pada gigi susu maupun gigi permanen. Karies gigi merupakan sebuah penyakit infeksi yang merusak struktur gigi, penyakit ini menyebabkan gigi berlubang, menyebabkan nyeri, gangguan tidur, penanggalan gigi, infeksi, berbagai kasus berbahaya dan bahkan kematian.(Norfai dkk, 2017).

Salah satu faktor yang dapat
menimbulkan karies adalah kegemaran mengonsumsi makanan manis. Makanan manis adalah makanan yang dapat menyebabkan terjadinya penyakit karies gigi. Sifat makanan manis adalah banyak mengandung karbohidrat, lengket dan mudah hancur di dalam mulut. Hubungan antara konsumsi karbohidrat dengan terjadinya penyakit karies gigi ada kaitannya dengan pembentukan plak pada permukaan gigi. Plak terbentuk dari sisa-sisa makanan yang melekat di sela-sela gigi dan pada plak ini akhirnya akan ditumbuhi bakteri yang dapat mengubah glukosa menjadi asam sehingga $\mathrm{pH}$ rongga mulut menurun sampai dengan 4,5. Pada keadaan demikian maka struktur email gigi akan terlarut. Pengulangan konsumsi karbohidrat yang terlalu sering menyebabkan produksi asam oleh bakteri menjadi lebih sering lagi sehingga keasaman rongga mulut menjadi lebih asam dan semakin banyak email yang terlarut.(Panna, S.S, 2012).

Berdasarkan hasil penelitian yang dilakukan oleh Eddy Rahman dkk (2018) menunjukkan bahwa berdasarkan hasil penelitian yang dilakukan di Madrasah Diniyah Islamiyah diperoleh bahwa proporsi mengonsumsi jajanan manis yang lumayan besar, sedangkan proporsi siswa yang tidak karies gigi dan mengonsumsi makanan manis yang kecil. Berdasarkan uji static hubungan antara kebiasaan mengonsumsi jajanan manis sebagai penyebab karies gigi diperoleh diperoleh hasil bahwa secara statistic ada hubungan antara kebiasaan mengonsumsi jajanan manis sebagai penyebab karies gigi pada anak di Madrasah Diniyah Islamiyah Muhammadiyah Kindaung Banjarmasin. Makanan seperti permen, cokelat, wafer, biskuit dan roti adalah jenis makanan yang sering dikonsumsi siswa Madrasah Diniyah Islamiyah Muhammadiyah Kindaung Banjarmasin pada saat jam istirahat. Makanan yang di konsumsi siswa ini merupakan jenis makanan manis yang lama kelamaan tertinggal di dalam gigi akan mengakibatkan terjadinya karies gigi.

Pada penelitian Sri Lestari dkk (2016) yang berjudul Hubungan antara kebiasaan konsumsi makanan manis dengan karies gigi anak usia sekolah juga dikemukakan bahwa pada penelitian yang dilakukan pada 40 siswa-siswi kelas VI SDN Kemanggisan 06 Jakarta Barat didapatkan sebagian besar responden memiliki kebiasaan konsumsi makanan manis dengan kategori tinggi sebanyak 55\% responden. Kemudian pada hasil penelitian untuk keadaan karies gigi menunjukkan prevalensi karies gigi sebesar $77,5 \%$ dan skor DMF-T rata-rata responden 2,60 termasuk kategori sedang, yang artinya rata-rata jumlah gigi karies pada satu siswa adalah kurang lebih 3 . Berdasarkan hasil uji statistik dipperoleh hasil bahwa terdapat adanya hubungan antara kebiasaan konsumsi makanan manis dengan karies gigi pada responden. Kesimpulan penelitian dari penelitian Sri Lestari dkk (2016) hasil penelitian menunjukkan bahwa makanan-makanan manis dapat mempengaruhi terjadinya karies gigi. Oleh karena itu kebiasaan pemeliharaan kesehatan gigi dan mulut perlu 
dilakukan sedini mungkin agar angka karies gigi dapat ditekan.

Pada penelitian Rizki Safira Talibo dkk (2016) juga di kemukakan bahwa : Hasil penelitian pada siswa kelas III SDN 1 dan 2 Sonuo yang berjumlah 40 responden yang frekuensi mengonsumsi makanan manis jarang dan mengalami karies gigi berjumlah 3 siswa sementara konsumsi makanan manis jarang dan tidak mengalami karies gigi berjumlah 10 siswa, sedangkan konsumsi makanan manis sering dan mengalami karies gigi berjumlah 26 siswa sementara konsumsi makanan manis sering dan tidak mengalami karies gigi berjumlah 1 siswa siswa. Hasil uji chi square menunjukkan bahwa terdapat hubungan antara frekuensi konsumsi makanan manis dengan kejadian karies gigi pada siswa kelas III SDN 1 dan 2 Sonuo, dengan demikian Ha diterima dan Ho ditolak.

Berdasarkan beberapa teori dari beberapa penelitian yang mendukung, hal tersebut membuktikan bahwa adanya hubungan antara mengonsumsi makanan manis terhadap tingkat kejadian karies. Semakin tinggi kegemaran anak mengonsumsi makanan manis maka angka kejadian karies juga akan tinggi. Tingginya tingkat konsumsi makanan manis cenderung akan meningkatkan resiko karies gigi pada anak usia sekolah, karena konsumsi makanan manis yang bersifat manis dan lengket dapat menyebabkan tersisanya makanan di dalam mulut. Sisa makanan tersebut mengendap dan berfermentasi menjadi asam sehingga menimbulkan plak pada gigi yang dapat meningkatkan resiko karies gigi. Karies juga bisa disebabkan oleh beberapa faktor lain selain kegemaran mengonsumsi makanan manis diantaranya keturunan, ras, jenis kelamin, usia, vitamin, unsur kimia, air ludah, mikroorganisme dalam mulut, serta plak. Oleh karena itu promosi kesehatan mengenai makanan manis dan pentingnya perawatan gigi yang benar perlu disosialisasikan pada semua pihak di sekolah.

\section{KESIMPULAN}

Berdasarkan beberapa penelitian yang sudah dikaji dan dianalisis didapatkan kesimpulan bahwa siswa yang memiliki tingkat konsumsi makanan manis tinggi akan memiliki resiko tinggi untuk terjadinya karies gigi, sedangkan siswa yang rendah konsumsi makanan manis akan mempunyai resiko yang rendah terhadap kejadian karies. Dengan demikian dapat disimpulkan bahwa ada hubungan yang signifikan antara kebiasaan mengonsumsi makanan manis dengan tingkat kejadian karies pada anak sekolah dasar.

\section{SARAN}

Adapun saran dari studi literatur ini adalah sebagai berikut :

1. Orang tua, guru dan tenaga kesehatan disarankan untuk melakukan sosialisasi tentang jenis makanan yang sehat untuk dikonsumsi anak usia sekolah dengan cara mengajarkan pada anak untuk memilih jenis makanan yang sehat agar terhindar dari karies gigi.

2. Hasil penilitian dengan metode literatur ini dapat dijadikan data dasar dalam pengembangan penelitian selanjutnya terkait dengan kejadian karies gigi dan sebagai data untuk mengembangkan promosi kesehatan berkaitan dengan pencegahan karies gigi pada anak usia sekolah.

\section{DAFTAR PUSTAKA}

Depkes RI. 2000. Profil Kesehatan Gigi dan Mulut di Indonesia. Jakarta: Departemen Kesehatan RI.

Fauzi, I. 2016. Hubungan Konsumsi Makanan Kariogenik dan Kebiasaan Menggosok Gigi dengan Karies Gigi pada Anak SDN 2 Cireundeu di Tangerang Selatan. Skripsi Fakultas Kedokteran dan IImu Kesehatan UIN Syarif Hidayatullah. 
Gusmawaty, 2004. Early Childhood Caries (ECC). Skripsi Fakultas Kedokteran Gigi Universitas Hasanuddin.

Linasari. 2013. Perilaku Konsumsi Makanan Kariogenik dan Menyikat Gigi Anak di SD Kecamatan Rajabasa Kota Bandar Lampung. Jurnal Keperawatan. Vol.IX No.1. Hal.37-42.

Hidayat, R, Tandiari, A. 2016. Kesehatan Gigi dan Mulut Apa yang Sebaiknya Anda Tahu? Yogyakarta: EGC

Machfoedz, I. 2008. Menjaga Kesehatan Gigi \& Mulut Anak-anak dan lbu Hamil. Yogyakarta: Fitramaya.

Mendur, S, Mintjelungan, C, dan Pangemanan, D. 2017. Gambaran Konsumsi Makanan Kariogenik pada Anak SD GMIM 1 Kawangkian. Jurnal e-GiGi (eG). Vol.V No.1. Hal.91-95.

Mumpuni, Y, Pratiwi, E. 2013. 45 Masalah dan Solusi Penyakit Gigi dan Mulut. Yogyakarta: Rapha Publishing.

Nuraliyah, R. 2013. Hubungan Kebiasaan Konsumsi Makanan Sumber Kalsium Dengan Kejadian Karies Gigi Pada Anak Sekolah Dasar.

Norfai, Rahman, E. 2017. Hubungan Pengetahuan dan Kebiasaan Menggosok Gigi dengan Kejadian Karies Gigi di SDI Darul Mu'minin Kota Banjarmasin Tahun 2017. Vol 8 No.1. Hal 212-218

Panna, SS. 2012. Hubungan Antara Frekuensi Konsumsi Makanan Kariogenik Dan Tingkat Keparahan Karies Gigi Molar Satu Permanen. Skripsi Universitas Hasanuddin.

Rahman, E, IImi, M.B, Anam, K. 2018. Kebiasaan Mengkonsumsi Jajanan Kariogenik Sebagai Penyebab Karies Gigi pada Anak di Madrasah Diniyah Islamiyah Muhammadiyah Kindaung Banjarmasin. Jurkessia. Vol.IX No.1. Hal.34-37.

Scheid, R.C, Weiss, G. 2013. Woelfel Anatomi Gigi Edisi 8. Jakarta: EGC.

Srigupta, A.A. 2004. Perawatan Gigi \& Mulut. Jakarta: Jakarta Prestasi Pustaka.

Suwelo, I.S. 1992. Petunjuk Praktis Sistem Merawat Gigi Anak di Klinik. Jakarta: EGC. Hal 78
Talibo, R.S, Mulyadi, Bataha, Y. 2016. Hubungan Frekuensi Makanan Kariogenik dan Kebiasaan Menggosok Gigi Dengan Kejadian Karies Gigi Pada Siswa Kelas III SDN 1 \& 2 Sonuo. e-Journal (e-KP). Vol.IV No.1. Hal 1-8

Taringan, E E. 2015. Pengaruh Penyuluhan Makanan Kariogenik dengan Metode Ceramah dan Diskusi Terhadap Pengetahuan Anak-anak Penderita Karies

Taringan, R. 2013. Karies Gigi Edisi 2. Jakarta: Penerbit Buku Kedokteran EGC. Hal 15-90

Gigi di SD Negeri 068004 Perumnas Simalingkar Medan 2015. Skripsi Fakultas Kesehatan Masyarakat Universitas Sumatra Utara. 